\title{
SEED CONDITIONING PROCESS IN THE SANITARY QUALITY OF MARANDU GRASS SEEDS
}

\author{
BENEFICIAMENTO NA QUALIDADE SANITÁRIA DE SEMENTES DE CAPIM- \\ MARANDÚ
}

\section{Tatiane Sanches JEROMINI'; Cibele Chalita MARTINS'; Givanildo Zildo da SILVA²; José de Oliveira CRUZ ${ }^{3}$}

1. Universidade Estadual Paulista "Júlio de Mesquita Filho", Campus Jaboticabal, Departamento de Produção Vegetal, Jaboticabal, SP, Brasil. tatiane_jeromini@hotmail.com; 2. Universidade Federal de Goiás/UFG - Regional de Jataí, Jataí-GO, Brasil; 3. Universidade de Brasília, Campus Brasília, Departamento de Agronomia e Medicina Veterinária, Brasília, DF, Brasil.

\begin{abstract}
The purpose of seed conditioning process is to separate seeds and their associated structures into different fractions and retain only good and healthy seeds. Thus, the aim of this study was to evaluate the effects the stages of seed conditioning have on the sanitary quality of marandu grass seeds. The seeds were sampled before and during the seed conditioning process, i.e., after exiting the air-screen cleaner and sieves (seeds discharged from the top, middle and bottom sieves), the first gravity separator (seeds drifting around the table, upper and intermediate discharge) and second gravity separator (upper, intermediate and lower discharge). The sanitary analysis was performed using the filter paper method with and without surface disinfestation of the seeds, which were incubated at $20 \pm 2^{\circ} \mathrm{C}$, with a photoperiod of 12 hours for seven days. The experiment was conducted in a completely randomized design, in a $2 \times 6$ factorial scheme (surface disinfestation $\mathrm{x}$ stages of the seed conditioning process) and ten replications. The data was submitted to analysis of variance, using the $\mathrm{F}$ test and, when significant, the means of the treatments were compared using the Tukey test at $5 \%$ probability. It was concluded that it is not possible to improve the sanitary quality of marandú grass seeds through the seed conditioning process.
\end{abstract}

KEYWORDS: Blotter test. Brachiaria brizantha. Seed sanity. Seed pathology.

\section{INTRODUCTION}

Seed conditioning allows for the improvement of the sanitary quality of the seeds by eliminating those infested with phytopathogens (MARCHI et al., 2010). However, this process can also increase the chances of contamination as the soil in the seed lots may be contaminated with reproductive fungi. Thus, when put inside the machines to be conditioned, the seeds could already be contaminated, as was verified in Panicum maximum cv. Tanzania and cv. Mombaça (MELO et al., 2017; SILVA et al., 2019).

Discharges from the conditioning of the seeds can also contribute to the dissemination of fungi, as these materials are usually acquired from low-tech forage seed companies to be mixed with the seed lots and to serve less demanding markets (HESSEL et al., 2012). Moreover, the seed conditioning plants usually contain a high amount of suspended dust in the air, which could result in the machines and seeds being contaminated by spores present in the dust particles (MELO et al., 2017).

Thus, it can be inferred that for better sanitary quality of seeds, there must be an improvement in the conditioning process of forage grass seeds (MARCHI et al., 2010). Tropical forage seeds may be an important vehicle for the spread of pathogens among different regions and few is known about their sanitary quality (VECHIATO; APARECIDO; FERNANDES, 2010). The presence of pathogens in the seeds results in a decrease in germination and vigor, which in turn, compromises the development and formation of the crop in the field (MARCHI et al., 2010; MALLMANN et al., 2013; MARCOS et al., 2015; MARTINS et al., 2017).

The main factors that have contributed to the production and commercialization of contaminated forage seed lots is the demand, by some consumers, for low prices at the expense of product quality (MARCHI et al., 2010).

However, with the expansion of pastures and intensification of livestock activity in recent years several diseases have begun to occur in pastures, increasing concerns about seed sanity. In addition, pathogens associated with these diseases have become significantly important in producing regions (MARCHI et al., 2009; MALLMANN et al., 2013).

The incidence of some potentially pathogenic fungi was reported in seeds of Panicum 
maximum and Brachiaria spp. such as Curvularia sp., Phoma sp., Fusarium sp., Exserohilum sp. (syn. Helminthosporium sp.), Cercospora sp., Colletotrichum spp., Drechslera sp., Alternaria sp., Rhizoctonia spp. (VECHIATO; APARECIDO; FERNANDES, 2010; SILVA et al., 2019). Fungi like Curvularia sp., Phoma sp., and Exserohilum sp. are responsible for diseases that cause rot, nonviable seeds and seedling death (MARCHI; FERNANDES; VERZIGNASSI, 2011).

Secondary metabolites and storage fungi, such as Aspergillus sp., Cladosporium sp., Epicoccum sp., Nigrospora sp., Penicillium sp. and Trichoderma sp., can be found in a lower incidence in P. maximum and Brachiaria spp. seeds. (MARCHI et al., 2010; MALLMANN et al., 2013; MARCOS et al., 2015; WITT et al., 2015).

The presence of pathogens may decrease the germination percentage, thus, preventing the seed lots from being sold or traded. In addition, these pathogens could be a barrier to exportation, due to the phytosanitary laws of certain countries. As seeds are a vehicle for dissemination, most countries that import forage seeds impose restrictions to Brazil (TSUHAKO, 2009). Thus, the aim of this study was to evaluate the effect of each stage of seed conditioning process has on the sanitary quality of marandu grass seeds.

\section{MATERIAL AND METHODS}

Marandu grass seeds were collected by an agricultural sweeper in certified seed production fields located in Monte Alegre de Minas, MG, Brazil. According to Alvares et al. (2014) the climate of the region is classified as Aw, with an average annual temperature of $22.4^{\circ} \mathrm{C}$ and rainfall of $1313 \mathrm{~mm}$ (INMET, 2017).

The seeds were processed in a seed conditioning plant for forage grasses by passing through an air-screen and sieves and two gravity separators measuring $2.40 \mathrm{~m}$ long and $1.25 \mathrm{~m}$ wide. The vibration velocity of the gravity separators was $1,750 \mathrm{rpm}$, and the transverse and longitudinal inclination were $17^{\circ}$ and $12^{\circ}$, respectively.

Samples were taken from the materials, as well as from the different machines, at each stage of the seed conditioning process resulting in 10 treatments (Figure 1).

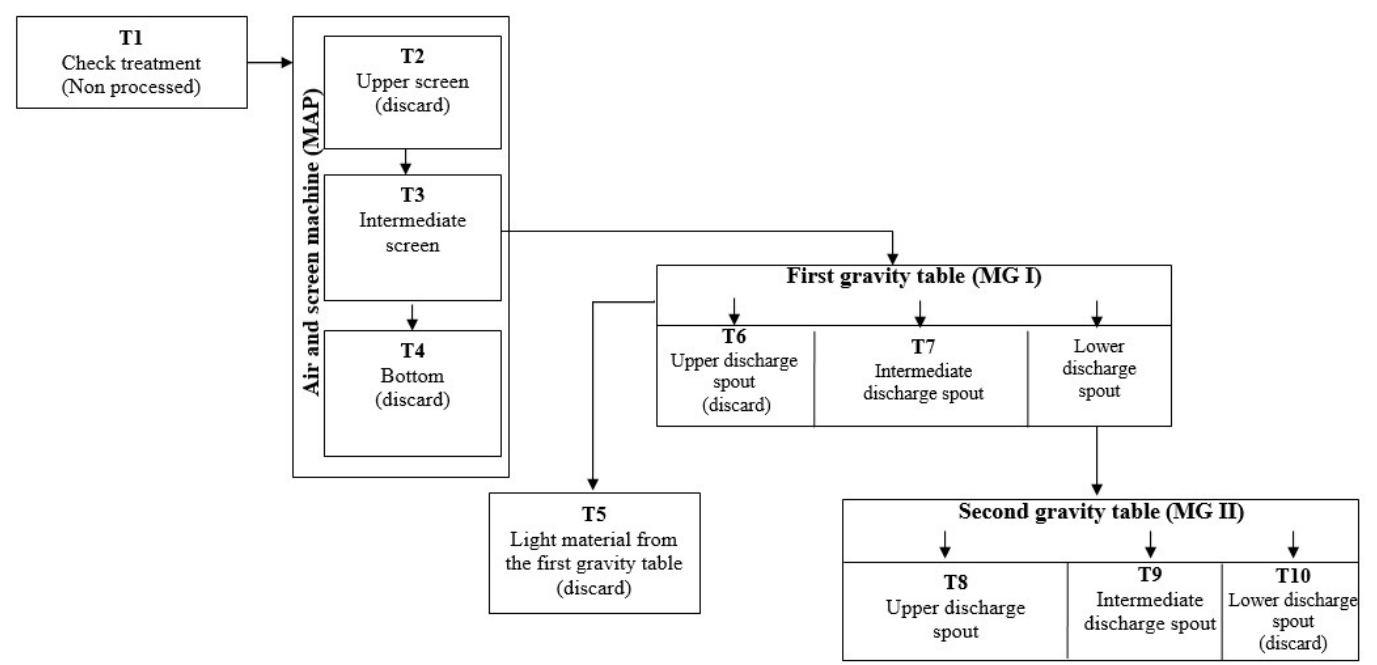

Figure 1. Flow diagram of seed conditioning process with points showing where the samples of marandu grass seeds were taken from, comprising the ten treatments.

Which treatments are described as: T1 - the control composed of the unprocessed seeds; T2 intermediate sieve from the air-screen and sieves, eight mesh and $18 \mathrm{~mm}$ bore; T3 - lower sieve of the air-screen and sieves, of 12 mesh of $26 \mathrm{~mm}$ bore; T4 - bottom of the air-screen and sieves, which were not retained in the sieves; T5 - from the first gravity separator, removed by vacuum machine at the entrance; T6 - upper discharge of the first gravity separator, collected at $40 \mathrm{~cm}$ from the highest end of the separator outlet, when considering the lateral slope of the table; T7 - intermediate discharge of the first gravity separator, in the intermediate segment of $50 \mathrm{~cm}$ from separator outlet; T8 - upper discharge of the second gravity separator, in the segment of $55 \mathrm{~cm}$ from the upper end of the separator outlet; T9 - intermediate discharge of the second gravity separator, in the intermediate segment of $40 \mathrm{~cm}$; T10 - lower discharge of the second gravity separator, in the segment $30 \mathrm{~cm}$ from the lower end (Figures 1, 2 and 3). 

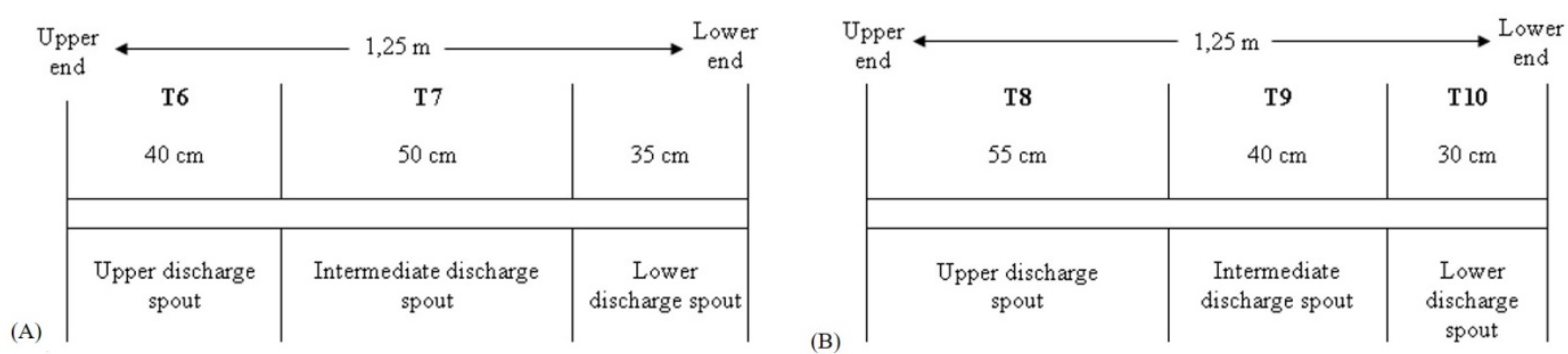

Figure 2. Sample collection points of Brachiaria brizantha $\mathrm{cv}$. Marandu from the first (A) and second gravity separator (B).
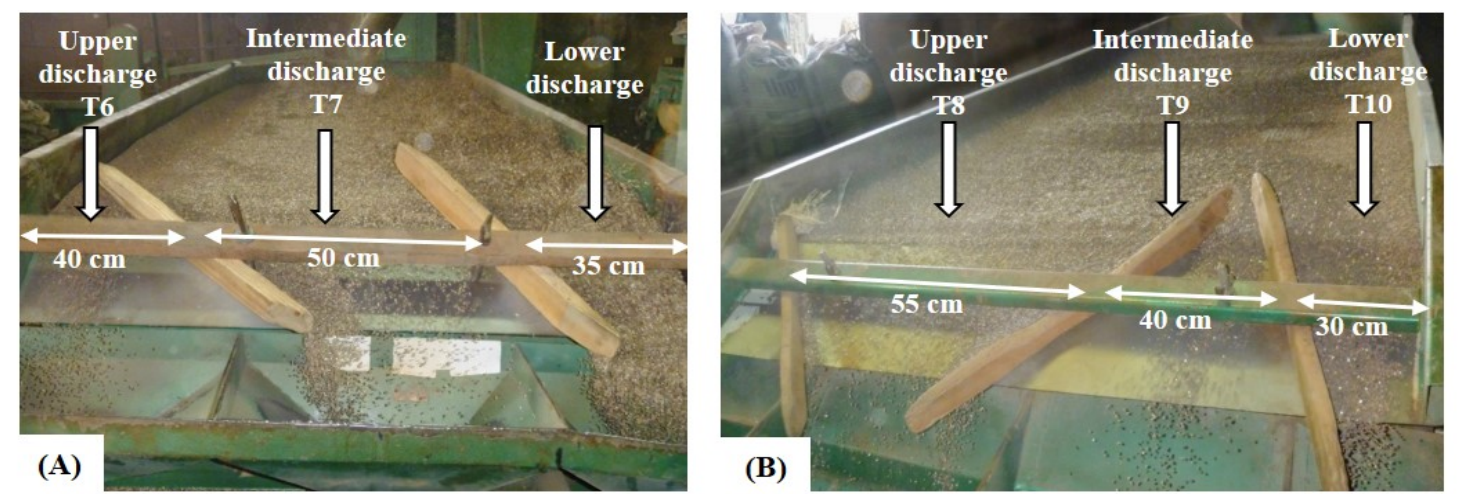

Figure 3. Sample collection points from the first (A) and the second gravity separator (B).

The divisions of discharge system of the two gravity separators were adjusted in order to allow for a higher concentration of undesirable materials to pass through the lower discharge, which is why they presented a variety of different sizes.

After stabilizing the machines, the seeds of each treatment (conditioning stage) were sampled at regular intervals, five minutes between each repetition, with 20 simple samples at an average weight of $100 \mathrm{~g}$ for each treatment being obtained from different discharge nozzles of the machines (MELO et al., 2016a,b; 2017). Samples obtained in each treatment were grouped and homogenized in composite samples and reduced to form average samples of $500 \mathrm{~g}$ each (BRASIL, 2009).

The samples were then taken to the seed analysis laboratory of Department of Plant Production - Plant Science, Faculty of Agrarian and Veterinary Sciences, Universidade Estadual Paulista "Júlio de Mesquita Filho", in Jaboticabal, SP, Brazil, which were reduced in a seed divider to obtain the study sample.

Sanitary analysis was carried out in the Laboratory of Seed Pathology of the Department of Phytosanitary of the Faculty of Agrarian and Veterinary Sciences - (UNESP), in Jaboticabal Campus, SP, Brazil. Ten replications of 10 seeds from each treatment were used, with and without surface disinfestation. Surface disinfestation was carried out by immersing the seeds in $\mathrm{NaClO}(1 \%)$ for three minutes, followed by rinsing with sterilized water and drying at room temperature $\left(25 \pm 3{ }^{\circ} \mathrm{C}\right)$.

Using the filter paper method (Blotter Test), the seeds were distributed at equal distance apart on three sheets of filter paper previously moistened with distilled water and incubated in $9.0 \mathrm{~cm}$ diameter Petri dishes for seven days at $20 \pm 2{ }^{\circ} \mathrm{C}$ and 12 hours of light. Afterwards, the seeds were analyzed individually under a stereoscopic microscope and the fungi were identified by means of morphological characteristics of their structures. The results were expressed as a percentage of contaminated seeds, for each fungus (BRASIL, 2009).

For seed sanitation, the experiments were evaluated in a completely randomized design, in a $2 \times 6$ factorial scheme (surface disinfestation $\mathrm{x}$ stages of the conditioning process) and ten replications. The data on fungi incidence found in the seeds (\%) was transformed into $(x+0,01)^{0,5}$ to meet the assumptions of the normality and homogeneity in Shapiro-Wilk tests. Averages of the original data were presented in the tables for a better interpretation of the results.

The data was submitted to analysis of variance, using the $\mathrm{F}$ test, and, when significant, the means of the treatments were compared using the Tukey test, at $5 \%$ probability. The data about the water content of the seeds before and after accelerated aging was not evaluated statistically. 


\section{RESULTS AND DISCUSSION}

Regardless of the stage the seed was in the conditioning process or the disinfestation procedure, 13 genera of fungi were detected in the sanitary analysis of marandu grass seeds: six had a high incidence, with values above of 5\%, such as Phoma sp., Alternaria sp., Fusarium sp., Exserohilum sp., Rhizoctonia sp. and Curvularia sp., (Figures 4 and 5).

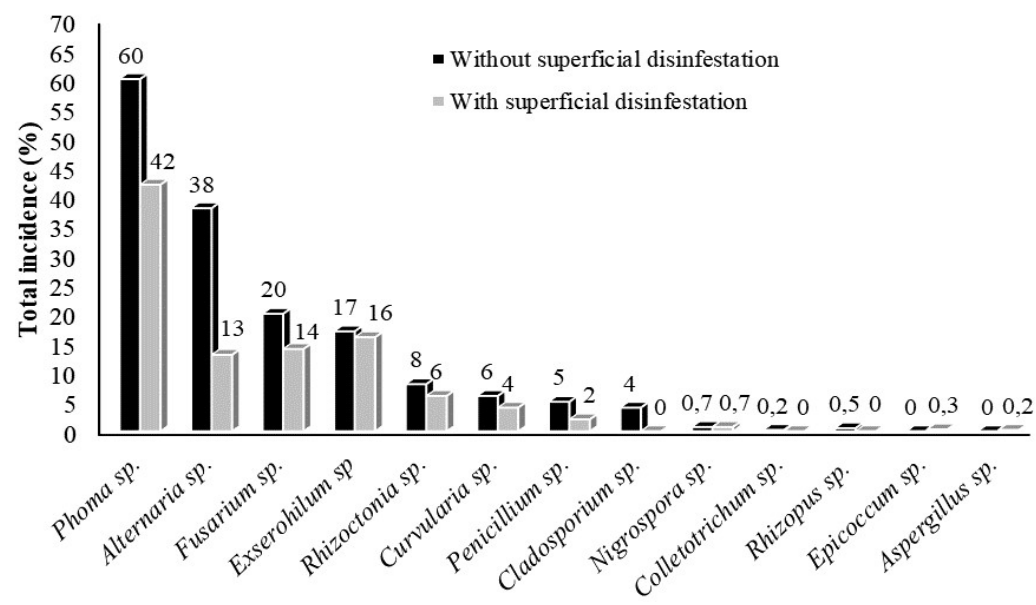

Figure 4. Fungal genera detected, with and without disinfestation, in marandu grass seeds in the conditioning process.

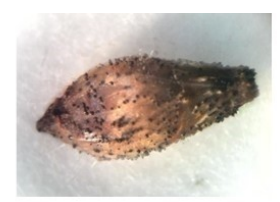

Phoma sp.

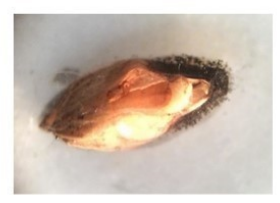

Exserohilum sp.

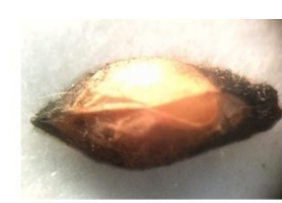

Alternaria sp.

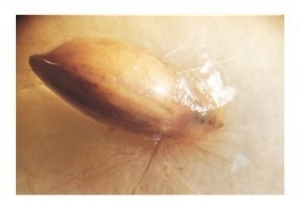

Rhizoctonia sp.

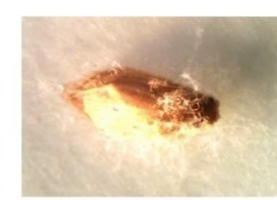

Fusarium sp.

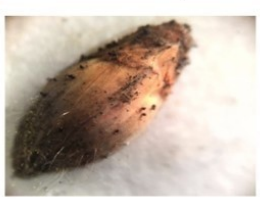

Curvularia $\mathrm{sp}$.

Figure 5. Marandu grass seeds infested by Phoma sp., Alternaria sp., Fusarium sp., Exserohilum sp., Rhizoctonia sp. and Curvularia sp. detected at higher percentage in the seeds during the conditioning process.

Other fungi were detected in low incidence, with values up to $5 \%$, such as Penicillium, Cladosporium, Nigrospora, Colletrotrichun, Rhizopus, Epicoccum and Aspergillus. Aspergillus sp., Cladosporium sp., Curvularia sp., Fusarium sp. and Phoma sp. had already been reported in seeds of $B$. brizantha cv. Marandu (MALLMANN et al., 2013). Martins et al. (2017) stated that the occurrence of these phytopathogens did not interfere in the germination of marandu grass seeds.

In contrast, Mentem et al. (1991) and Mallmann et al. (2013) reported that high levels of pathogenic fungi such as Fusarium sp. and Phoma sp. are of concern since they grow fast and aggressively and can result in seed death even before germination.
Almost all the fungi were found at lower incidence rate after the external disinfestation of the seeds when compared with values before desinfestation, except for Epicoccum sp. and Aspergilus sp. which were not affected by the disinfestation procedure (Figure 4). The structures of these fungi were probably located within the seeds and the disinfestation with sodium hypochlorite did not influence the microorganisms.

Among the fungi studied, interaction between the conditioning process and the disinfestation procedure was verified only on incidence percentage of Exserohilum sp. and Alternaria sp. in the seeds (Table 1). 
Table 1. Incidence of Exserohilum sp. and Alternaria sp. in marandu grass seeds with (CD) and without superficial disinfestation (SD) with sodium hypochlorite, according to stages of the conditioning process.

\begin{tabular}{|c|c|c|c|c|}
\hline \multirow{2}{*}{ Conditioning process ${ }^{1}$} & \multicolumn{2}{|c|}{ Exserohilum sp. (\%) } & \multicolumn{2}{|c|}{ Alternaria sp. (\%) } \\
\hline & SD & $\mathrm{CD}$ & SD & $\mathrm{CD}$ \\
\hline T1 - Control (unprocessed seeds) & $28 \mathrm{bB}$ & $11 \mathrm{abA}$ & $49 \mathrm{aB}$ & $14 \mathrm{abA}$ \\
\hline T3 - Lower sieve of MAP & $21 \mathrm{bB}$ & $8 \mathrm{aA}$ & $34 \mathrm{aB}$ & $10 \mathrm{abA}$ \\
\hline T6 - Upper discharge of MG I & $15 \mathrm{abB}$ & $5 \mathrm{aA}$ & $35 \mathrm{aA}$ & $22 \mathrm{bA}$ \\
\hline T7 - Intermediate discharge of MG I & $21 \mathrm{abA}$ & 18 abA & $28 \mathrm{aB}$ & $10 \mathrm{aA}$ \\
\hline T8 - Upper discharge of MG II & $12 \mathrm{abA}$ & $28 \mathrm{bB}$ & $29 \mathrm{aA}$ & $16 \mathrm{abA}$ \\
\hline T9 - Intermediate discharge of MG II & $7 \mathrm{aA}$ & $26 \mathrm{bB}$ & $51 \mathrm{aB}$ & $8 \mathrm{aA}$ \\
\hline F Disinfestation (D) & \multicolumn{2}{|c|}{$1,15^{\mathrm{ns}}$} & \multicolumn{2}{|c|}{$101,26^{* *}$} \\
\hline F Conditioning process $(\mathrm{CP})$ & \multicolumn{2}{|c|}{$1,80^{\mathrm{ns}}$} & \multicolumn{2}{|c|}{$2,25^{\mathrm{ns}}$} \\
\hline $\mathrm{F}(\mathrm{DxCP})$ & \multicolumn{2}{|c|}{$8,59 * *$} & \multicolumn{2}{|c|}{$4,14 * *$} \\
\hline C. V. \% & \multicolumn{2}{|c|}{55,50} & \multicolumn{2}{|c|}{33,28} \\
\hline
\end{tabular}

For Exserohilum sp., the stages of the conditioning process, influenced the seeds that had not been subjected to disinfestation. In this case, the seeds from the intermediate discharge of the second gravity separator (T9) presented the lowest incidence of this fungus with values significantly lower than those presented by the seeds from the control (T1) and, even, the intermediate sieve of the air-screen and sieves (T3). However, they did not differ from the other treatments (Table 1).

However, even though there is a lower incidence of Exserohilum sp. in this sample, the seeds are not able to be sold or traded, as they did not present the percentage of purity and germination required by the Normative Instruction for the production and commercialization of $B$. brizantha seeds (BRASIL, 2008).

The surface disinfestation significantly reduced the incidence of Exserohilum sp. in seeds from the control group (T1), as well as, in those coming from the inferior sieve of the air-screen and sieves (T3) and in the seeds from the top discharge of the first gravity separator (T6). However, in the upper and intermediate discharges from the second gravity separator (T8 and $\mathrm{T} 9$ ), that is, in the last stages of the conditioning process, there was a higher incidence of this fungus in seeds subjected to disinfestation (Table 1). This is possibly due to the presence of spores of the fungus being housed internally in the seeds and when disinfestation was carried out there was a decrease in competition with other fungi on the seed surface and, thus, higher proliferation of Exserohilum sp. (QUADROS et al., 2012; AMORIM et al., 2016).
It is worth noting that Exserohilum sp. can be transmitted to the seedlings by being present in the seed as reported by Lasca, Vechiato and Kohara (2004) and may cause leaf and stem stains, drying of the leaves and death of the plant (TSUHAKO, 2009). This fungus has been reported in seed lots of marandu grass and xaraes grass from several regions (MARTINS et al., 2017).

The stages of the conditioning process did not influence the incidence of Alternaria sp. in the marandu grass seeds, with or without surface disinfestation, as none of the treatments differed from the control. Regarding the disinfestation process, it reduced the incidence of Alternaria sp. in the control (T1), intermediary sieves from the airscreen and sieves (T3) and intermediary discharges of the first and second gravity separator (T7 and T9) (Table 1).

Therefore, it was found that a significant percentage of structures of this fungus were lodged superficially on the seeds, and could be disseminated by the machines during the seed conditioning process, through impregnated soil and dust in the equipment and suspended in the environment, causing there not to be a decrease in the incidence of Alternaria sp.

Nevertheless, the presence of this pathogen in the seeds was higher than 5\% (Table 1 and Figure 4). This would represent a high potential of inoculum, since the genus Alternaria is potentially pathogenic among forage grasses and their structures that lodge in inner layers of the seed cannot be eliminated with superficial disinfestation (VECHIATO; APARECIDO; FERNANDES, 2010). 
There was no interaction between the stages of seed conditioning and the disinfestation procedure with Rhizoctonia sp. and Curvularia sp. in marandu grass seeds (Table 2). Thus, possibly, these fungi were housed both inside and on the surface of the seeds.

Table 2. Incidence of fungi Rhizoctonia sp. and Curvularia sp. in Brachiaria brizantha cv. Marandu seeds according to the stages of the seed conditioning process.

\begin{tabular}{lcc}
\hline Conditioning process $^{1}$ & Rhizoctonia sp. (\%) & Curvularia sp. (\%) \\
\cline { 2 - 3 } T1 - Control (unprocessed seeds) & $8 \mathrm{ab}$ & $6 \mathrm{~b}$ \\
T3 - Lower sieve of MAP & $14 \mathrm{~b}$ & $2 \mathrm{a}$ \\
T6 - Upper discharge of MG I & $5 \mathrm{ab}$ & $4 \mathrm{ab}$ \\
T7 - Intermediate discharge of MG I & $7 \mathrm{ab}$ & $9 \mathrm{c}$ \\
T8 - Upper discharge of MG II & $5 \mathrm{ab}$ & $3 \mathrm{a}$ \\
T9 - Intermediate discharge of MG II & $2 \mathrm{a}$ & $8 \mathrm{~b}$ \\
\hline F Disinfestation (D) & $4,13^{*}$ & $0,86^{\mathrm{ns}}$ \\
F Conditioning process (CP) & $2,82^{*}$ & $2,34^{*}$ \\
F (DxE) & $1,15^{\text {ns }}$ & $0,94^{\text {ns }}$ \\
C. V. \% & 126,33 & 127,45 \\
\hline * and $^{\text {ns }}$ Significant at 5\% and not significant by the test F. Means followed by the same lowercase letter in the column and of the same \\
capital letter in the row, do not differ among themselves by the Tukey test at 5\% probability. MAP- air-screen and sieves, MGI- first \\
gravity separator, MGII- second gravity separator. ${ }^{1}$ The results of the analysis of T2, T4, T5 and T10 treatments were not presented due \\
to the absence of seeds in the sample.
\end{tabular}

The percentage incidence of Rhizoctonia sp. applied in treatments T3, T6, T7, T8 and T9 did not differ statistically from $\mathrm{T} 1$ (Table 2). It is worth noting that any of the evaluated treatments would go to the market with the presence of Rhizoctonia sp. This is important mainly because this pathogen, among other fungi, has been reported as responsible for the sudden death of marandu grass pastures, which is one of the main causes of pasture loss in Brazil (MARCHI; FERNANDES; VERZIGNASSI, 2011).

Regarding the effect the stages of the conditioning process have on the incidence of Curvularia sp., the highest percentage of contaminated seeds were selected in the intermediate discharge of the first gravity separator (T7). The lowest percentage of seeds with this fungus was obtained in the sample from the intermediate sieve of the air-screen and sieves (T3) and in the upper discharge of the second gravity separator (T8). Therefore, it is possible to infer that the seeds of greater weight had a higher percentage of incidence of this fungus (Tables 1,2).
The genus Curvularia occurs in grasses and has saprophytic behavior, surviving in organic soil matter (SIVANESAN, 1987). Possibly, the seeds of forage grasses that are located at the apex of the panicle were better fed by the plant, well formed, heavier and dispersed first, remaining in contact with the contaminated soil for a longer time until the time of harvest (NERY et al., 2012). Thus, a higher incidence of the pathogen was found in these heavier seeds than the lighter seeds that formed and were dispersed later and thus remain for less time on the soil before being harvested.

\section{CONCLUSION}

The seed conditioning process was not able to improve the sanitary quality of the marandu grass seeds.

\section{ACKNOWLEDGEMENT}

To the Conselho Nacional de Desenvolvimento Científico e Tecnológico (CNPq) and the company Marangatú.

RESUMO: A finalidade do beneficiamento de sementes é separar as sementes e suas estruturas associadas em diferentes frações e reter apenas sementes boas e saudáveis. O objetivo deste trabalho foi avaliar o efeito das etapas do beneficiamento sobre a qualidade sanitária de sementes de capim-marandú. As sementes foram amostradas antes e durante o beneficiamento: após a saída da máquina de ar e peneiras (descarga das peneiras superior, intermediária e fundo), primeira mesa gravitacional (deriva ao redor da mesa, descarga superior e intermediária) e segunda mesa gravitacional (descarga superior, intermediária e inferior). A análise sanitária foi realizada pelo método do papel de filtro com e sem desinfestação superficial das sementes, as quais 
foram incubadas a $20 \pm 2{ }^{\circ} \mathrm{C}$, com fotoperíodo de $12 \mathrm{~h}$ durante sete dias. O experimento foi conduzido em delineamento inteiramente casualizado, em esquema fatorial $2 \times 6$ (desinfestação superficial $\mathrm{x}$ etapas do beneficiamento) e dez repetições. Os dados foram submetidos à análise de variância pelo teste $\mathrm{F}$ e quando significativa, as médias dos tratamentos comparadas pelo teste de Tukey, a 5\% de probabilidade. Foi possível concluir que o beneficiamento não é capaz de melhorar a qualidade sanitária das sementes de capim-marandú.

PALAVRAS-CHAVE: Blotter test. Brachiaria brizantha. Sanidade. Patologia de sementes.

\section{REFERENCES}

ALVARES, C. A.; STAPE, J. L.; SENTELHAS, P. C.; GONÇALVES, J. L. M; GERD SPAROVEK, G. Köppen's climate classification map for Brazil. Meteorologische Zeitschrift, Stuttgart, v. 22, n. 6, p.711-728, 2014. DOI 10.1127/0941-2948/2013/0507

AMORIM, L.; REZENDE, J. A. M.; BERGAMIN FILHO, A.; CAMARGO, L. E. A. Manual de fitopatologia: Doenças das plantas cultivadas. São Paulo: Agronômica Ceres, 2016. 573p.

BRASIL. Ministério da Agricultura, Pecuária e do Abastecimento Gabinete do Ministro. Instrução Normativa $\mathbf{n}^{0}$ 30, de 21 de maio de 2008. Diário Oficial da União, Poder Executivo, 23 de maio de 2008, Seção 1, p. 45.

BRASIL. Ministério da Agricultura, Pecuária e Abastecimento. Regras para análise de sementes. Brasília, DF: MAPA/ACS, 2009. 398p.

HESSEL, C. L. E.; VILLELA, F. A.; AUMONDE, T. Z.; PEDÓ, T. Mesa densimétrica e qualidade fisiológica de sementes de brachiária. Informativo ABRATES, Londrina, v. 22, n. 3, p. 73-76, nov. 2012.

INSTITUTO NACIONAL DE METEOROLOGIA. Banco de Dados Meteorológicos para Ensino e Pesquisa. Disponível em: http://www.inmet.gov.br/portal/index.php?r=bdmep/bdmep. Acesso em: 11 de agosto de 2017.

LASCA, C. C.; VECHIATO, M. H.; KOHARA, E. Y. Controle de fungos de sementes de Brachiaria spp.: eficiência de fungicidas e influência do período de armazenamento de sementes tratadas sobre a ação desses produtos. Arquivos do Instituto Biológico, São Paulo, v. 71, n. 4, p. 465-472, out/dez. 2004.

MALLMANN, G.; VERZIGNASSI, J. R.; FERNANDES, C. D.; SANTOS, J. M.; VECHIATO, M. H.; INÁCIO, C. A.; BATISTA, M. V.; QUEIROZ, C. A. Fungos e nematoides associados a sementes de forrageiras tropicais. Summa Phytopathologica, Botucatu, v. 39, n. 3, p. 201-203, dez. 2013. https://doi.org/10.1590/S0100-54052013000300010

MARCHI, C. E.; FERNANDES, C. D.; FABRIS, L.; JERBA, V.; SORGATTO, M. Incidência de Ustilago operta em sementes comerciais de braquiária. Arquivos do Instituto Biológico, São Paulo, v. 76, n. 1, p. 121125, jan. 2009. Disponível em: <http://www.biologico.sp.gov.br/docs/arq/v76_1/marchi.pdf>. Acesso em: 27 fevereiro, 2016

MARCHI, C. E; FERNANDES, C. D; BUENO, M. L; BATISTA, M. V; FABRIS, L. R. Fungos veiculados por sementes comerciais de braquiária. Arquivos do Instituto Biológico, São Paulo, v.77, n.1, p.65-73, 2010. Disponível em: <http://www.biologico.sp.gov.br/docs/arq/v77_1/marchi.pdf $>$. Acesso em: 27 fevereiro, 2016

MARCHI, C. E.; FERNANDES, C.; VERZIGNASSI, J. R. Doenças em plantas forrageiras. Campo Grande, MS: Embrapa Gado de Corte, 2011. 32p. 
MARCOS, M. F.; JANK, L.; FERNANDES, C. D.; VERZIGNASSI, J. R.; MALLMANN, G.; QUEIRÓZ, C. A.; BATISTA, M. V. Reação à Bipolaris maydis, agente causal da mancha foliar, em híbridos apomíticos de Panicum maximum. Summa Phytopathologica, Botucatu, v. 41, n. 3, p. 197-201, set. 2015. http://dx.doi.org/10.1590/0100-5405/2078

MARTINS, C. C., DE MELO, P. A. F. R., PEREIRA, F. E. C. B., DOS ANJOS NETO, A. P., \& DO NASCIMENTO, L. C. Sanitary quality of Brachiaria brizantha cv. Marandu and Xaraés seeds harvested in different states in Brazil. Bioscience Journal, Uberlândia, v. 33, n. 6, p. 1431-1440, nov. 2017. https://doi.org/10.14393/BJ-v33n6a2017-36533

MELO, L. F.; MARTINS, C. C.; DA SILVA, G. Z.; BONETI, J. E. B.; VIEIRA, R. D. Beneficiamento na qualidade física e fisiológica de sementes de capim-mombaça. Revista Ciência Agronômica, Fortaleza, v. 47, n. 4, p. 667-674, out/dez. 2016a. https://doi.org/10.5935/1806-6690.20160080

MELO, L. F.; MARTINS, C. C.; SILVA, G. Z.; SANCHES, M. F. G. Processing in the quality of Tanzania grass seeds. Engenharia Agrícola, Jaboticabal, v. 36, n. 6, p. 1157-1166, out/dez. 2016b. http://dx.doi.org/10.1590/1809-4430-Eng.Agric.v36n6p1157-1166/2016

MELO, L. F.; SILVA, G. Z. D.; PANIZZI, R. C.; MARTINS, C. C. Processing on the sanitary quality of seeds of Panicum maximum cv. 'Tanzânia'. Revista Brasileira de Engenharia Agrícola e Ambiental, Campina Grande, v. 21, n.10, p.715-720, ago. 2017. http://dx.doi.org/10.1590/1807-1929/agriambi.v21n10p715-720

MENTEM, J. O. M. Patógeno em sementes: deteç̧ão, dano e controle químico. Piracicaba: Fealq, 1991, $312 \mathrm{p}$.

NERY, M. C.; NERY, F. C.; SILVA, D. R. G.; SOARES, F. P. Produção de sementes forrageiras. Universidade Federal de Lavras, Departamento de Ciência do Solo. Boletim Técnico, n.88, p. 1-47, 2012.

QUADROS, D. G. de; ANDRADE, A. P.; OLIVEIRA, G. C. de; OLIVEIRA, E. P.; MOSCON, E. S. Componentes da produção e qualidade de sementes dos cultivares Marandú e Xaraés de Brachiaria brizantha (Hochst. ex A. Rich.) Stapf colhidas por varredura manual ou mecanizada. Semina Ciências Agrárias, v.33, p.2019- 2028, 2012. https://doi.org/10.5433/1679-0359.2012v33n5p2019

SILVA, G. Z. da, MARTINS, C. C.; MELO, L. F. de, JEROMINI, T. S.; PANIZZI, R. D. C. Incidence of fungi in mombasa grass seeds during the stages of the seed conditioning process. Engenharia Agrícola, Jaboticabal, v. 39, n. 2, p. 234-239, mar/abr, 2019. http://dx.doi.org/10.1590/1809-4430-eng.agric.v39n2p234-239/2019

SIVANESAN, A. Graminicolous species of Bipolaris, Curvularia, Drechslera, Exserohilum and their teleomorphs. Wallingford: CAB International, 1987, 261p.

TSUHAKO, A. T. Exportação de sementes de forrageiras tropicais. 2009. Disponível em: $<$ http://www.matsuda.com.br/administracao/arquivo/Sementes\%20de\%20Forrageiras\%20-\%20Seed\% 20News\%20abr\%202006. doc>. Acesso em: 31 set. 2017.

VECHIATO, M. H. APARECIDO, C. C.; FERNANDES, C. D. Frequência de fungos em lotes de sementes comercializadas de Brachiaria e Panicum. Comunicado Técnico do Instituto Biológico: São Paulo. Centro de Pesquisa e Desenvolvimento de Sanidade Vegetal, 2010. n. 7, 11p.

WITT, F. A. P.; DE OLIVEIRA, F. F.; TAKESHITA, V.; RIBEIRO, L. F. C. Qualidade sanitária de sementes de Urochloa e Panicum comercializada no Norte Matogrossense. Enciclopédia Biosfera, Goiânia, v. 11, n. 21, p. 16-36, jan. 2015. 